\title{
Hubungan Dukungan Sosial dan Kecemasan dalam Menghadapi Dunia Kerja pada Mahasiswa Akhir
}

\author{
Alif Tri Santo \& Ilham Nur Alfian* \\ Departemen Psikologi Sosial, Fakultas Psikologi Universitas Airlangga
}

\begin{abstract}
ABSTRAK
Pandemi yang sedang terjadi memperburuk keadaan yang membuat 39.977 perusahaan melakukan PHK dan berdampak pada 1.010.579 pekerja, hal tersebut membuat mahasiswa yang akan menghadapi dunia kerja mengalami kecemasan. Penelitian ini bertujuan untuk mengetahui hubungan antara kecemasan dalam menghadapi dunia kerja dan dukungan sosial. Penelitian ini dilakukan pada 150 mahasiswa dengan kriteria mahasiswa dengan semester 7 atau lebih Data diperoleh menggunakan metode survey yang menggunakan alat ukur skala dukungan sosial dan kecemasan dalam menghadapi dunia kerja. Teknik analisis data yang digunakan dalam penelitian ini adalah Pearson Product Moment. Hasil analisis menunjukkan korelasi sebesar -0,437 yang berarti terdapat hubungan negatif antara dukungan sosial dengan kecemasan dalam menghadapi dunia kerja pada mahasiswa tingkat akhir yang artinya apabila dukungan sosial yang diterima oleh individu tinggi maka kecemasan dalam menghadapi dunia kerja akan turun, begitu juga sebaliknya.
\end{abstract}

Kata kunci: dukungan sosial, kecemasan dalam menghadapi dunia kerja

\begin{abstract}
Pandemic has exacerbated the situation which caused 39,977 companies and impact 1,010,579 workers, this makes students who will face the world of work experience worry. This study aims to determine the relationship between job-seeking anxiety work and social support. This research was conducted on 150 students with the criteria of students with 7 semesters or above. The data were obtained using a survey method that uses a scale measuring tool for social support and anxiety in facing the world of work. The data analysis technique used in this research is Pearson Product Moment. The results of the analysis show a correlation of -0.437 , which means that there is a negative relationship between social support and job-seeking anxiety in final year students, which means that if the social support received by individuals is high, job-seeking anxiety will decrease, and vice versa.
\end{abstract}

Keywords: job-seeking anxiety, social support

Buletin Penelitian Psikologi dan Kesehatan Mental (BRPKM), 2021, Vol. 1(1), 370-378

*Alamat korespondensi: Fakultas Psikologi Universitas Airlangga, Kampus B Universitas Airlangga Jalan Airlangga 4-6 Surabaya 60286. Surel: ilham.nuralfian@psikologi.unair.ac.id 


\section{PE N D A H U L U A N}

Masyarakat mulai menyadari pentingnya pendidikan tinggi dalam meningkatkan taraf hidup. Strata satu atau S1 merupakan cara untuk memperoleh lebih banyak pengetahuan dan keterampilan, sehingga mereka dapat menguasai keterampilan yang tidak dimiliki oleh orang yang berpendidikan rendah (Soemanto, 2006) namun pada kenyataannya orang yang berpendidikan lebih tinggi mungkin tidak mendapatkan pekerjaan.

Statistik (2020) menyebutkan Jumlah pekerja dalam badan statistic pada Februari 2020 sebanyak 13,791 juta, meningkat 1,73 juta dari Februari 2019. Dibandingkan dengan kenaikan jumlah tenaga kerja, tingkat partisipasi angkatan kerja (TPAK) turun sebesar 015 persen.

Tahun 2019 hingga dengan 2020 pengangguran meningkat 60 ribu orang, berbeda dengan TPT yang turun jadi 4, 99 persen pada Februari 2020. Dilihat pada tingkatan pembelajaran, TPT Sekolah Menengah Kejuruan Sekolah Menengah Kejuruan (SMK) masih yang sangat besar ialah sebesar 8, 49 persen, perihal ini melebihi tingkatan pembelajaran lain (Statistik, 2020). Hal tersebut bertambah buruk dengan adanya pandemi yang terjadi pada tahun 2020 yaitu Corona, dari perspektif pekerja, pengusaha dan perusahaan independen, terlihat dampak pandemi Covid 19 terhadap dunia ketenagakerjaan Indonesia. Dari perspektif pekerja, akibat terganggunya kegiatan usaha di sebagian besar sektor, gelombang PHK dan berkurangnya pendapatan. Corona yang menghambat kegiatan ekonomi secara otomatis akan menyebabkan pelaku usaha mengalami kerugian, yang mengakibatkan banyak pekerja yang dipecat atau bahkan dipecat. Menurut data Kementerian Tenaga Kerja (Kemnaker) per 7 April 2020, 39.977 perusahaan di sektor formal telah melakukan PHK dan PHK karyawan akibat pandemi Covid-19. Jumlah pekerja yang terkena dampak ini adalah 1.010.579.

Menghadapi kejadian ini, banyak orang berusaha untuk menaikan kemampuannya. Satu dari banyak cara adalah pendidikan formal, menurut Papalia (2008) pendidikan dapat meningkatkan kesempatan kerja dan memungkinkan untuk menghasilkan uang. Oleh karena itu, setiap orang terus mengenyam pendidikan formal dan beralih ke pendidikan tinggi untuk meningkatkan kemampuan akademiknya.

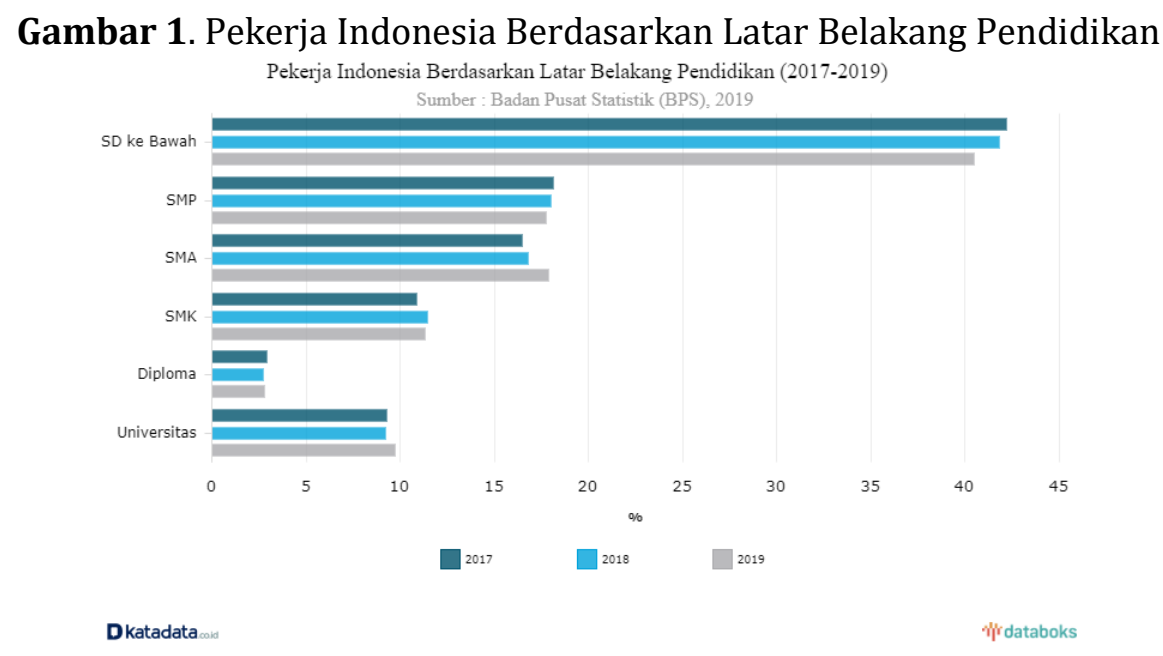

Sumber: (Statistik, 2020)

Data menunjukkan sulitnya bagi lulusan perguruan tinggi untuk mendapatkan pekerjaan. Hal tersebut terlihat karena banyak mahasiswa perguruan tinggi yang sudah lulus masih menjadi pengangguran. 
Terlihat di bulan Februari 2019, jumlah tersebut masih dibatasi untuk pekerja dengan pendidikan sekolah dasar atau di bawahnya, terhitung 40,51\%. Meskipun terjadi penurunan sekitar 1\% dibandingkan tahun 2017 sebesar 42,23\%, angka tersebut tidak berubah dalam tiga tahun terakhir. Serta dalam gambar diatas lulusan sarjana atau mahasiswa strata satu hanya menempati 2,8\% pekerjaan pada tahun 2019 yang mana menurun dari tahun 2017 sebesar 0,13\% yang artinya sangat sedikit dari lulusan sarjana yang mendapat pekerjaan dari tahun ke tahun bahwa mengalami sedikit penurunan.

Data tersebut merupakan data terbaru dari BPS ketenagakerjaan, namun dikarenakan pandemi yang terjadi selama tahun 2020 dapat dipastikan bahwa lapangan pekerjaan akan berkurang. Survey yang diadakan oleh LIPI atau Lembaga Ilmu Pengetahuan Indonesia Hingga 20 April 2020, 2.084 .593 pekerja dari 116.370 perusahaan telah di-PHK (Ngadi, 2020). Hal tersebut merupakan adanya perusahaan yang mengurangi produksi atau bahkan menghentikan produksinya.

Setelah menyelesaikan studi di perguruan tinggi dan universitas, tantangan yang dihadapi mahasiswa di dunia kerja akan menimbulkan emosi negatif, satu dari dampaknya merupakan kecemasan. Hal tersebut sesuai dengan hasil penelitian Beiter (2015) dimana ditunjukkan bahwa dibandingkan dengan mahasiswa tingkat bawah, mahasiswa pada tahun terakhir lebih cemas tentang perencanaan pasca universitas dan pencarian kerja setelah lulus. Menurut Prasetyo (2008) kecemasan juga membuat mahasiswa kesulitan dalam menyelesaikan studinya.

Masalah lainnya muncul saat mahasiswa yang sedang mencari pekerjaan menggangap bahwa proses mencari pekerjaan dianggap sulit dan berkaitan dengan emosi negatif (Wanberg, 2010). Emosi negative dapat beruapa banyak hal, namun salah satunya yang dirasakan oleh mahasiswa yaitu kecemasan, gangguan kecemasan mengacu pada keadaan emosi yang ditandai dengan gejala fisik, perasaan tegang yang tidak menyenangkan dan hal-hal buruk yang umumnya terjadi (Nevid, 2005).

Dalam Penelitian Liu (2009) meningkatnya tekanan lapangan kerja menyebabkan kecemasan mahasiswa semakin meningkat. Tingkat pekerjaan di jurusan yang berbeda mungkin memainkan peran positif dalam kecemasan. Terdapat perbedaan kecemasan yang dialami mahasiswa dari berbagai jurusan studi yang mereka ambil. kecemasan berada dalam kurva yang menurun dari pengobatan Cina dan barat, kedokteran klinis, teknik biomedis dan keperawatan. tetapi siswa keperawatan menunjukkan kecemasan yang sangat rendah.

Kecemasan dalam menghadapi dunia kerja ini dapat menurunkan performa kerja atau bahkan lebih buruk lagi. Kecemasan dapat menyebabkan takut berbicara di depan umum, takut berinteraksi dengan sosok penting pada perusahaan, takut dalam mengambil tantangan baru, takut sehingga terlihat gelisah dan cemas (Jones, 2020).

Gejala fisik yang timbul saat mahasiswa merasa cemas antara lain jantung yang berdetak terlalu cepat, berkeringat, bibir kering, gemetar, pusing, dan gejala-gejala fisik lain. Gejala mental mungkin termasuk seseorang yang akan merasa akan kehilangan kendali dan dirugikan oleh situasi yang akan datang. Salah satu contoh gangguan berupa gejala perilaku yaitu saat individu menghindari situasi tertentu secara berkala meyakinkan orang lain bahwa semuanya akan baik-baik saja (Kearney, 2012).

Taylor (2011) menemukan bahwa dukungan sosial dapat mengurangi kecemasan. Dukungan sosial juga berpengaruh terhadap depresi pada masa-masa stress yang dapat diperoleh dari berbagai aspek yaitu Keluarga, pasangan, orang tua, teman sebaya dan komunitas (Sarafino, 1998). 
Jika mahasiswa menerima dukungan sosial dari lingkungan, mereka akan secara aktif memandang pengalaman sebagai sesuatu yang tidak terlalu mencemaskan, serta merasa aman dan nyaman karena merasa diperhatikan, dicintai, dan dapat diterima dengan baik di lingkungan tersebut (Amylia, 2014). Dukungan sosial sangat penting untuk mahasiswa yang sedang mengalami kecemasan, karena dukungan sosial menjadi sangat berharga ketika seseorang menghadapi suatu masalah, sehingga individu yang bersangkutan membutuhkan orang terdekat yang dapat dipercaya untuk membantu menyelesaikan masalah tersebut (Rif'ati, 2018).

Pendapat yang sama dengan hal tersebut, Uchino dalam (Sarafino, 1998) menyatakan bahwa dukungan sosial adalah suatu bentuk kenyamanan, perasaan diperhatikan dan dihormati, serta merupakan bantuan yang diperoleh seseorang dari orang lain. Dukungan sosial bisa datang dari semua pihak, baik orang tua, pasangan, keluarga, sahabat, dan komunitas social.

Dukungan sosial akan mebantu menurunkan kecemasan mahasiswa dalam dunia kerja, terutama dukungan sosial diterima individu (Fauziyah, 2015). Bentuk dukungan tersebut meliputi dukungan informasi, pertemanan, apresiasi dan dukungan instrumental.

\section{Desain Penelitian}

\section{E T O D E}

Tipe riset ini memakai tata cara kuantitatif. Riset tipe ini meruapakan riset yang digunakan buat mempelajari populasi ataupun ilustrasi tertentu. Pengumpulan informasi ini memakai perlengkapan riset analisis informasi kuantitatif ataupun statistik buat menguji hipotesis yang sudah didetetapkan (Prihatsanti, 2018). Jenis yang digunakan dalam penelitian ini adalah korelasi. Korelasi adalah analisis yang digunakan untuk mengetahui ada tidaknya hubungan antara dua variabel (Azwar, 2010), dua variabel disini yaitu hubungan dukungan sosial dengan kecemasan dalam menghadapi dunia kerja pada mahasiswa akhir Universitas Airlangga.

\section{Partisipan}

Partisipan yang terlibat penelitian ini sebanyak 150 responden yang dipilih secara acak dan sukarela. Kriteria partisipan merupakan mahasiswa tingkat akhir Universitas Airlangga. Pengumpulan data dilakukan dalam jaringan (daring) secara sukarela melalui Google Form. Dalam menentukan jumlah partisipan, penulis menghitung dengan bantuan rumus yang ada didalam buku Pallant (2012) dan diperoleh hasil yaitu minimal 66 responden.

\section{Pengukuran}

\section{Alat Ukur Kecemasan dalam Menghadapi Dunia Kerja}

Kecemasan dalam menghadapi dunia kerja merupakan penilaian individu terhadap pencapaian tujuan yang tidak pasti di dunia kerja. Dengan cara ini, konflik terjadi dalam diri individu sehingga menimbulkan perubahan perilaku, seperti menghindari segala sesuatu yang berhubungan dengan dunia kerja dan menghancurkan reaksi fisiologis lainnya.

Penelitian ini mengukur Kecemasan dalam menghadapi dunia kerja dengan menggunakan skala yang didasarkan pada berbagai aspek kecemasan yang meliputi gejala fisik, gejala kognitif, dan gejala perilaku. Jumlah aitem alat ukur ini adalah 19. Untuk mengukur kecemasan penulis menggunakan alat 
ukur kecemasan dalam menghadapi dunia kerja yang terdiri dari 19 aitem dengan koefisien reliabilitas yang cukup baik $(\alpha=.731)$. Di bawah ini adalah Blueprint skala kecemasan dalam menghadapi dunia kerja:

Tabel 1. Alat Ukur Kecemasan dalam Menghadapi Dunia Kerja

\begin{tabular}{ccccc}
\hline \multirow{2}{*}{ No } & Indikator & \multicolumn{2}{c}{ Sebaran Item } & \multirow{2}{*}{ Jumlah } \\
\cline { 3 - 4 } & & Favorable & Unfavorable & \\
\hline 1 & Reaksi fisik & $2,9,15$ & $1,6,11$ & 6 \\
2 & Pemikiran & $3,8,13$ & 16,19 & 5 \\
3 & Perilaku & $7,12,14$ & 4,17 & 5 \\
4 & Suasana Hati & 5,18 & 10 & 3 \\
& Total & 11 & 8 & 19 \\
\hline
\end{tabular}

Alat Ukur Mutidimensional Scale perceived sosial support

Untuk mengukur dukungan sosial yang diterima mahasiswa, peneliti menggunakan alat ukur skala multidimensional perceived social support untuk mengetahui dukungan sosial. Alat ukur ini dikembangkan oleh Zimet (1998) dan mempunyai 3 dimensi yaitu dukungan keluarga, dukungan teman dan significant other. Penulis melalui proses adaptasi, mula-mula menerjemahkan semua item ke dalam bahasa Indonesia, kemudian penerjemah lain menerjemahkannya kembali ke dalam bahasa Inggris. Kemudian, penulis meminta pertimbangan professional judgement untuk mengkritisi dan menyarankan kualitas alat ukur tersebut. Berdasarkan masukan evaluator, penulis melakukan beberapa perubahan sebelum digunakan sebagai alat pengumpul data. Instrumen tes dan pengukuran yang digunakan penulis sama dengan objek penelitian yang asli. Jumlah item alat ukur ini adalah 12 . Untuk mengukur dukungan sosial penulis menggunakan mutidimensional scale perceived sosial support yang terdiri dari 12 aitem dengan dengan koefisien reliabilitas yang cukup baik $(\alpha=.776)$.

Di bawah ini adalah blueprint skala dukungan sosial:

Tabel 2. Alat Ukur Multidimensional Perceived Social Support

\begin{tabular}{lccc}
\hline \multicolumn{1}{c}{ Dimensi } & $\begin{array}{c}\text { Nomor Aitem } \\
\text { Favorable }\end{array}$ & $\begin{array}{c}\text { Nomor Aitem } \\
\text { Unfavorable }\end{array}$ & Jumlah \\
\hline Dukungan Keluarga & $3,4,8,12$ & - & 4 \\
Dukungan Teman & $6,7,9,11$ & - & 4 \\
Dukungan Significant & $1,2,5,10$ & - & 4 \\
Other & & & \\
\hline TOTAL AITEM & 12 & 0 & 12 \\
\hline
\end{tabular}

\section{Analisis Data}

Metode analisis informasi dalam riset ini memakai metode korelasi product- moment, tujuan metode tersebut merupakan buat mengenali ikatan antar variabel riset ialah (variabel X serta Y). Proses analisa informasi yang digunakan dalam riset ini memakai Windows SPSS 25. 0. 


\section{HAS I L P E N EL I T I A N}

Berdasarkan hasil analisis deskriptif yang dilakukan dapat diketahui bahwa untuk variabel Kecemasan dalam menghadapi dunia kerja diperoleh nilai minimum sebesar 34, nilai maksimum sebesar 70, mean sebesar 48.50 dan standar deviasi sebesar 8.415. Variabel dukungan sosial diperoleh nilai minimum sebesar 22, nilai maksimum sebesar 79, mean sebesar 55.94 dan standar deviasi sebesar 12.276.

Hasil pengujian terkait menunjukkan bahwa hubungan antara kecemasan di dunia kerja dan dukungan sosial dapat dilihat dari nilai korelasi Pearson. Diketahui bahwa nilai signifikansi antara variabel dukungan keluarga, teman, dan significant other dengan Kecemasan dalam menghadapi dunia kerja menunjukan angka 0,00. Uji korelasi dapat dikatakan apabila memiliki nilai signifikansi kurang dari 0,05. Hal ini menunjukan bahwa hasil uji hipotesis korelasi kedua variabel tersebut yaitu variabel dukungan sosial dan variabel Kecemasan dalam menghadapi dunia kerja memiliki hubungan yang signifikan. Terdapat hubungan yang sedang dan negatif antara Kecemasan dalam menghadapi dunia kerja dengan dukungan sosial $[\mathrm{r}=-0,437, \mathrm{n}=150, \mathrm{p}>0,05]$, yang berarti tingginya dukungan sosial maka semakin rendah kecemasan dalam menghadapi dunia kerja dan juga sebaliknya.

\section{I S K U S I}

Berdasarkan hasil penelitian yang menggunakan uji korelasi Pearson Product Moment yang digunakan untuk mengetahui arah dan kekuatan hubungan antar dua variabel yang diteliti. Terdapat hubungan yang sedang dan negative antara Kecemasan dalam menghadapi dunia kerja dengan dukungan sosial hal tersebut dapat dilihat dari hasil korelasi dukungan sosial memiliki nilai sebesar $-0,437$. Sehingga hal tersebut sesuai dengan hipotesis awal dimana Ha diterima, sedangkan Ho ditolak dan semakin tinggi dukungan sosial akan berhubungan dengan rendahnya kecemasan dalam menghadapi dunia kerja.

Mahasiswa tingkat akhir yang sedang mencari pekerjaan merasa sulit untuk mendapatkan pekerjaan dan akan menimbulkan emosi negatif (Wanberg, 2010). Mahasiswa yang tidak yakin apakah perusahaan akan menerima pekerjaan, gaji, masa kerja, kolega dan supervisor, dan kemampuan pribadi saat individu juga akan menghadapi dunia kerja akan mengalami kecemasan. (Alkhathami, 2014).

Hal ini sesuai dengan penelitian yang dilakukan oleh Fauziyah (2015) dimana terdapat hubungan negatif antara dukungan sosial teman sebaya dengan kecemasan menghadapi dunia kerja, hasil penelitian mendapat koefisien korelasi sebesar -0,537.

Faktor lain juga ditemukan oleh Nadziri (2018) dimana jurusan subjek dalam penelitian ini adalah seni, sastra, desain grafis, dan guru olahraga. Berdasarkan hasil penelitiannya dapat diketahui bahwa jurusan sastra memiliki kecemasan yang tinggi dan jurusan yang lain memiliki presentase yang sedang. Daradjat dalam Rizky (Wicaksono, 2016) mahasiswa takut dan cemas dalam menghadapi karier masa depan karena lapangan pekerjaan yang semakin sempit serta ketatnya dalam bidang pekerjaan.

Penelitian Amylia (2014) menyebutkan apabila dukungan sosial yang diterima individu dari lingkungan secara positif, maka individu tersebut akan menggangap kejadian yang telah terjadi kepada dirinya menjadi sesuatu yang tidak terlalu buruk sehingga rasa cemas yang dialami akan berkurang dan merasa aman serta nyaman karena merasa diperhatikan, dicintai dan dirinya dapat diterima di lingkungan dengan baik. Mahasiswa tingkatan akhir memerlukan sokongan social karena dukungan sosial menjadi sangat berharga kala orang hadapi sesuatu permasalahan oleh sebab itu orang yang bersangkutan membutuhkan orang-orang terdekat yang dapat dipercaya untuk membantu dalam mengatasi permasalahannya tersebut (Rif'ati, 2018). 


\section{S I M P U L A N}

Berdasarkan hasil analisis data beserta kajian literasi sebelumnya, penelitian ini menyimpulkan bahwa terdapat hubungan antara dukungan sosial dan Kecemasan dalam menghadapi dunia kerja pada mahasiswa tingkat akhir di Universitas Airlangga. Hubungan ini bersifat negatif yang artinya apabila salah satu nilai variabel meningkat maka nilai variabel yang lain akan turun, begitu juga dengan sebaliknya.

\section{U C A P A N T ERIMA KASIH}

Alhamdulillah, puji syukur kehadirat Allah SWT sebab atas berkat rahmat serta hidayahnya, penulis diberi kelancaran serta kemudahan buat menuntaskan skripsi dengan judul“ Ikatan Sokongan Sosial Serta Kecemasan Mengalami Dunia Kerja Pada Mahasiswa Akhir Di Universitas Airlangga” bagaikan salah satu prasyarat supaya bisa memperoleh gelar Sarjana Psikologi Universitas Airlangga Surabaya. Penulis menyadari skripsi yang sudah ditulis ini tidak hendak berakhir tanpa dorongan serta sokongan dari banyak pihak yang ikut andil dalam proses pengerjaannya. Oleh sebab itu pada peluang ini, penulis mau mengantarkan terima kasih kepada.

1. Prof. Dr. Suryanto, M.Si., Psikolog selaku Dekan Fakultas Psikologi Universitas Airlangga Surabaya

2. Rizqy Amelia Zein, S.Psi., M.Sc. selaku dosen wali penulis yang telah memberikan dukungan selama penulis berkuliah di Fakultas Psikologi Universitas Airlangga Surabaya

3. Ilham Nur Alfian, M.Psi., Psikolog. Selaku dosen pembimbing skripsi yang telah memberikan waktu luang untuk menuntun dan membimbing selama penyusunan skripsi.

4. Ibu saya yang telah mendoakan saya selama ini, beserta bapak saya yang telah mendukung dalam segala hal termasuk wifi dirumah dan tidak lupa sanak saudara yang telah mendukung saya.

\section{DEKLARASI POTENSI TERJADINYAKONFLIK KEPENTINGAN}

Alif Tri Santo dan Ilham Nur Alfian tidak bekerja, menjadi konsultan, memiliki saham, atau menerima dana dari perusahaan atau organisasi manapun yang mungkin akan mengambil untung dari diterbitkannya naskah ini.

\section{PUSTAKA ACUAN}

Alkhathami, S. (2014). Social anxiety and quality of life in adolescents: cognitive aspect, social interaction and cultural tendency.

Amylia, Y. \&. (2014). Hubungan antara persepsi dukungan sosial dengan tingkat kecemasan pada penderita leukemia. Jurnal Psikologi Klinis dan Kesehatan Mental, 79-84.

Beiter, R. N. (2015). The prevalence and correlates of depression, anxiety, and stress in a sample of college students. Journal of affective disorders, 90-96. 
Fauziyah, F. K. (2015). Dukungan Sosial Teman Sebaya danKecemasan dalam Menghadapi Dunia Kerja pada Mahasiswa S1 Tingkat Akhir. Empati, 4, 255-261.

Feldman, M. A. (2008). Home Visiting Programs: Primary and Secondary Prevention in At-risk Children. Early Intervention, 184.

Greenberger, D. \&. (1995). Mind over Mood: a cognitive therapy treatment manual for clients. Guilford press.

Jones, C. (2020, 04 15). How Anxiety Hurts Workplace Productivity. Retrieved from The Business Journals: https://www.bizjournals.com/bizjournals/how-to/growth-strategies/2017/10/howanxiety-hurts-workplace-

productivity.html\#: :text=People $\% 20$ who $\% 20$ experience $\% 20$ anxiety $\% 20$ at,mention $\% 20$ the $\% 2$ 0time\%20commitment\%20involved.

Kearney, C. A. (2012). Abnormal psychology and life: A dimensional approch. Wadsworth: Belmont.

Liu KR, H. G. (2009). Psychological anxiety evaluation and analysis of graduates at a medical university under employment pressure. Nan Fang Yi Ke Da Xие Xие Bao, 5, 1071-1072.

Nadziri, M. (2018). Kecemasan Menghadapi Dunia Kerja Pada Mahasiswa Akhir Dengan Jurusan Yang Diprediksi Sulit Mendapat Pekerjaan.

Nevid, J. S. (2005). Psikologi abnormal. Jakarta: Erlangga,.

Ngadi. (2020, 05 04). Survei Dampak Darurat Virus Corona terhadap Tenaga Kerja Indonesia. Retrieved from Lembaga Ilmu Pengetahuan Indonesia: http://lipi.go.id/siaranpress/survei-dampak-daruratvirus-corona-terhadap--tenaga-kerja-indonesia/22030

Papalia, D. E. (2008). Human development (psikologi perkembangan). Jakarta: Kencana.

Prasetyo, A. \&. (2008). Pengaruh Stres terhadap Komitmen Mahasiswa-Mahasiswa Universitas Airlangga untuk Menyelesaikan Pendidikan Mereka dengan Faktor Kecemasan sebagai Variabel Moderator. urnal Ekonomi dan Bisnis Airlangga (JEBA)/Journal of Economics and Business Airlangga, 18.

Rif ati, M. I. (2018). Konsep Dukungan Sosial. Jurnal penelitian: Fakultas Psikologi Universitas Airlangga Surabaya.

Sarafino, E. P. (1998). Health Psychology, Third Edition. New York: John Wiley \& Sons.

Soemanto, W. (2006). Psikologi pendidikan: Landasan kerja pemimpin pendidikan. Jakarta: Rineka Cipta.

Statistik, B. P. (2020). Statistik Indonesia 2020.

Taylor, S. E. (2011). Social support: A review.

Wanberg, C. R. (2010). The job search grind: Perceived progress, self-reactions, and self-regulation of search effort. Academy of Management Journal, 53, 788-807. 
Wicaksono, D. R. (2016). Hubungan antara Dukungan Sosial dengan Kecemasan Menghadapi Dunia Kerja Pada Siswa SMK.

Zimet, G. D. (1998). The multidimensional scale of perceived social support. Journal of personality assessment, 30-41. 